\title{
Back to work or stay at home? Family policies and maternal employment in Finland
}

\section{Eva Österbacka ${ }^{1}$ (D) . Tapio Räsänen ${ }^{2}$ (D)}

Received: 13 December 2019 / Accepted: 19 March 2021 / Published online: 27 April 2021

(C) The Author(s) 2021

\begin{abstract}
The employment effects of family policies depend on the mother's labor market attachment and on the age of the child. We study the effects of child home care (cash-for-care) and private day care allowances on mothers' return to employment after childbirth. Our identification strategy exploits changes in municipal-level subsidies. We find that higher private day care allowances have no effect while higher home care allowances increase the length of home care. A 100-euro higher level of home care allowance prolongs home care by 2-3 months, on average. The home care allowance combined with low labor market attachment and low earnings potential pre-birth delay the return to employment. However, the effect of the allowance diminishes over time. Higher subsidies have no impact by the time a child turns two. Reductions in subsidies stimulate a faster return to employment.
\end{abstract}

Keywords Maternal labor supply $\cdot$ Child-care subsidies · Family policy $\cdot$ Gender equality

JEL Classification $\mathrm{J} 22 \cdot \mathrm{J} 13 \cdot \mathrm{J} 18 \cdot \mathrm{J} 16$

\section{Introduction}

Family formation and family policies affect female labor force participation. New mothers generally decrease their time spent in paid work while increasing their time

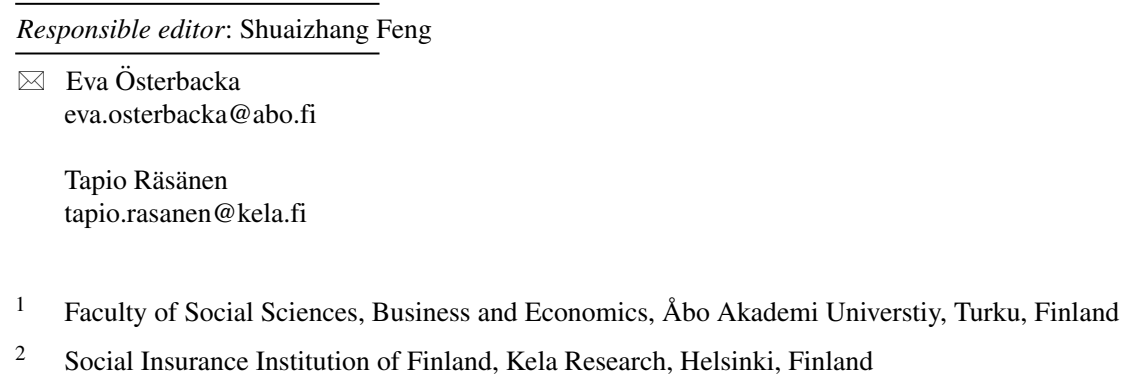


spent in unpaid work. Long periods of family leave benefits generally extend home care among mothers and reduce female labor supply, while support for child care outside the family increases female labor supply. The length of maternal child-care leave is affected by incentives and preferences, which are, in turn, affected by both individual and family characteristics and furthermore by family policies (Leibowitz et al. 1992; Apps and Rees 2004; Kangas and Rostgaard 2007; Burgess et al. 2008; Pronzato 2009; Ulker and Guven 2011; Olivetti and Petrongolo 2017).

However, policy effects depend not only on individual and family characteristics but also on the age of the child. We use the Finnish context to study how family policies and the age of the child affect the timing of maternal return to the labor market after childbirth. A distinct feature of Finnish family policy is that parents can choose between home care and day care for their young children. Finland both offers public support for home care of children under the age of three and subsidizes day care heavily. We scrutinize heterogeneous and dynamic effects of these family policies, in particular the effect of the home care allowance (also called cash-for-care) when affordable and good-quality day care is available.

The Nordic countries have considerably gender equality in a global context, but Finland deviates somewhat. Female labor force participation was already high by the 1970s, although it has not increased that much since then. Female labor force participation is lower than in the other Nordic countries, partly due to the possibility of financial support for the home care of children under 3 years old, and the gender pay gap is wider (OECD 2018). Attitudes regarding traditional gender roles are more positive in Finland compared to other Nordic countries, and close to attitudes in other European countries (Salin et al. 2016; Ylikännö et al. 2016). For instance, Engster and Stensöta (2011) examine a dual career-earner and a family policy support index and find that, among the Nordic countries, Finland is closest to Central European and German countries. In that sense, results from Finland can be generalized not only to more gender-equal countries but also to countries where more conservative norms are prevalent.

Family policies matter for female labor force participation. The effects vary and some policies may have unintended consequences (Hegewisch and Gornick 2011). In the Finnish context, previous research shows that the home care allowance reduces labor force participation among mothers. Furthermore, take-up varies by labor market status before childbirth (Lammi-Taskula 2004; Peutere et al. 2014; Kosonen 2014; Kosonen and Huttunen 2018). In the German context, Kuhlenkasper and Kauermann (2010) and Fitzenberger et al. (2013) point out that the replacement rates of family benefits, the duration of job-protection periods, and previous labor market attachment among mothers have dynamic effects on the duration of the home care period. We contribute to the literature by showing that family policies have both heterogeneous and dynamic effects on families with small children by using extensive Finnish register data. The results show that altering the level of the home care allowance influences the length of home care. However, the effect fades with the age of the child.

By using municipal differences in subsidies to families and changes in replacement rates by the age of the child, we report causal policy effects. Our identification strategy exploits changes in municipal-level subsidies over the years. The treatment group consists of mothers living in municipalities that have increased the subsidies 
while the control group consists of mothers living in other municipalities. A causal identification requires that policy implementations are exogenous to the treated mothers. We find support for a causal interpretation. First, the increase in the subsidy is uncorrelated with the outcomes of the treated before the increase. Second, the difference between control and treatment groups is stable before the increase of the subsidy. These, and other, identification assumptions are further discussed in Section 5.3, and results from identification tests are presented in Appendix B. But first, we introduce the concept, the institutional context, the data set, and the empirical strategy.

\section{Background}

\subsection{Theoretical framework and previous findings}

Adding a child to the family is a big decision. In the new home economics theory, the choice to become parents is a rational decision, based on preferences, costs and benefits of children, and income constraints (Becker 1991). The costs related to children are both direct and indirect. Indirect costs include opportunity costs related to reduced labor force participation, for which mothers usually take the main responsibility. Mincer and Polachek (1974) point out that time outside the labor market can result in not only forgone earnings but also lost human capital. In their seminal work, Mincer and Polachek (1974) show that the higher the education level among mothers, the higher the wage penalty for child-care leaves. Opportunity costs for child-care leaves vary among women with different types of labor market attachments. In a recent meta-analysis, Cukrowska-Torzewska and Matysiak (2020) show that the wage penalty can generally be explained by the deterioration of human capital due to child-care leaves.

Family policies alter the costs related to children, hence are likely to affect the labor force participation among mothers. Firstly, when child-care leaves are publicly financed, the immediate costs of forgone earnings are partly covered. Secondly, public support for alternatives to home care alters the budget constraints, which affect the timing of the return to the labor market. Policies can increase or reduce the relative price of day care.

Policies that increase the relative price of day care should decrease labor force participation among mothers. By studying the introduction of home care allowance in Norway, Kornstad and Thoresen (2007) found support for reduced employment due to increased relative price of day care. They argue that decisions on labor force participation and child care are interrelated through the income level that labor force participation generates which in turn implies child-care arrangements. However, the introduction of home care allowance in Norway did not affect fathers' working hours. Naz (2004) argues that this implies, in addition, an increased value of mothers' time at home and increased specialization. In general, the introduction of home care allowance reduces labor force participation (Rønsen and Sundström 2002; Naz 2004; Schøne 2004; Kornstad and Thoresen 2007; Giuliani and Duvander 2017).

Policies that reduce the relative price of day care should increase the employment rate. Generally, support for child care outside the family increases labor supply 
among mothers (Apps and Rees 2004; Kangas and Rostgaard 2007; Ulker and Guven 2011; Olivetti and Petrongolo 2017).

Heterogeneous policy effects are likely to arise when support for home care changes by the age of the child or when the level of reimbursement varies between individuals. Burgess et al. (2008) propose a theoretical framework for examining the effects of maternity leave rights and other factors that influence the decision to return to work after childbirth. The mother chooses between returning to work and staying home taking care of her child over a period where she meets altering budget constraints over time. In addition to budget constraints, individual preferences affect the decision as well. By considering that support for home care changes by the age of the child and that the level of reimbursement varies between individuals, Burgess et al. (2008) show that discontinuities and level differences in opportunity sets affect the choice of when to return to work. They argue that when the benefit level decreases, clustering should occur. Due to the discontinuities and level differences in opportunity sets, mothers can make similar decisions even with different preferences. Correspondingly, similar preferences can lead to different decisions. As a consequence, policy effects are heterogeneous.

In the Finnish context, Lammi-Taskula (2004) and Peutere et al. (2014) stated that mothers use home care allowance to a larger extent if they have poor labor market attachment before childbirth. With municipal variation in home care allowance supplements in Finnish data, Kosonen (2014) and Kosonen and Huttunen (2018) found causal effects of higher subsidies on reduced labor force participation among mothers.

Furthermore, changes over time will have different effects for mothers with different opportunity costs to home care. For instance, Kuhlenkasper and Kauermann (2010) analyze the dynamic behavior of German mothers and find some dynamic effects on the timing of the return to the labor market. The most important dynamic effects are found between the parental leave system and women's labor market attachment before and between births.

On a more general level, previous research shows that personal and family characteristics affect the duration of mothers' child-care leaves (Gutiérrez-Doménech 2005; Burgess et al. 2008; Matysiak and Vignoli 2008; Kuhlenkasper and Kauermann 2010; Gerster and Lappegård 2010; Fitzenberger et al. 2013). These characteristics reflect preferences and choices made before childbirth. Mothers who were attached to the labor market before giving birth are more likely to return sooner. Mothers with higher opportunity costs for staying at home for longer periods, that is, highly educated mothers with higher pre-birth earnings, are more likely to return sooner. Marital status can affect the decision as well. If the father is able to support the family, the mother is likely to take care of their child longer.

Some of these above-mentioned empirical studies argue for estimating causal effects on maternal employment, for instance (Schøne 2004; Fitzenberger et al. 2013; Kosonen 2014; Kosonen and Huttunen 2018). To our knowledge, there are few extensive results on the heterogeneous and dynamic effects of childbirth on maternal employment decisions. Fitzenberger et al. (2013) estimate causal effects of the first child, by using a dynamic treatment approach with German mothers. Their main findings are that the employment effects differ by age and educational groups. Kosonen 
(2014) also finds differences in causal employment effects by educational group. In contrast to these analyses, we estimate both causal effects for the timing of the return to employment and furthermore, heterogeneous and dynamic effects.

\subsection{Institutional background of the Finnish family policies}

The Finnish welfare state offers several benefits and services to children and their families. Finland has universal parental leave and child-care policies to which all Finnish residents are entitled. The responsibility for services and transfers targeted at families are divided between the state and municipalities. Child-care leaves are organized on the state level and parental leave legislation applies to all employers and employees. Similarly, maximum day care fees, minimum home care allowance, and minimum private day care allowance are set at state level. Day care is organized and financed at municipal level. Municipalities may decide to pay additional subsidies, municipal supplements, to support home care or private day care of children. Available municipal supplements are likely to affect mothers' incentives to return to work which we use as our identification strategy in this study.

Generally, the replacement rate of earnings-related parental leave benefits is more generous while the home care allowance is low even with the municipal level supplements. After the earnings-related parental leave period, when the child is around nine months old, parents may choose between returning to the labor market and using subsidized day care services or taking care of the child at home and receiving home care allowance. ${ }^{1}$ Home care allowance is a flat rate allowance allowed to families, whose youngest child is under 3 years of age and does not attend public day care. ${ }^{2}$ In accordance with national labor force legislation, parents have the right to return to their former employer if their employment contract covers the leave period. The same applies for those who use parental leave only. ${ }^{3,4}$

A large share, around $90 \%$ of families, uses a period of home care allowance to add to their parental leave. Mothers are mainly the ones to stay at home and care for their children, but the length of the period varies. ${ }^{5}$

\footnotetext{
${ }^{1}$ See Fig. 4 in the Appendix for more details on parental leaves and care allowances.

${ }^{2}$ The older siblings are often cared for at home as well, which increases the level of the allowance (as well as municipal supplements and statutory supplements for low-income families - that is, often for single parents). In this sense, the Finnish system is unique, as no other country financially supports the home care of children over 3 years old.

${ }^{3}$ Employers are obliged to offer posts with conditional tenure. Temporary posts are still possible, such as substitution (for mothers on parental leave) or fixed-term projects.

${ }^{4}$ If the parent receiving home care allowance does not have a job to return to, they can chose to apply for unemployment benefits. In this case, they are obliged to accept a job offer. If they are not willing to return to the labor market, they are not entitled to any other public support except last-resort social assistance. Alternatively, and this is likely, having another child entitles the mother to renewed parental leave benefits.

5 During the research period, the use of home care has decreased. In 2000, home care allowance was used to support the home care of $58 \%$ of children between the ages of 9 months and 2 years. This share decreased to less than $50 \%$ by 2010 (Kela 2016). The explanation for the decline in home care is that the longest home care allowance periods (over 24 months) have decreased markedly. At the same time, shorter home care allowance periods have, in fact, become more prevalent (Salmi and Närvi 2017).
} 
During the research period, all families with children under school age are entitled to public day care or financial support for private day care. Municipalities are obliged to arrange day care for children under the school age residing in the municipality. The municipalities can arrange the care themselves or authorize private day care providers. Families who choose private day care providers are entitled to a private day care allowance offered from the state. The fee for private day care is generally higher than the fee for public day care, but still affordable due to the private day care allowance. The out-of-pocket costs for public and private day care are quite close at least for the more affluent parents, who are the most likely users of private day care (Takala 2000). Most families use public day care. ${ }^{6}$

We use the municipal differences in subsidies to families to estimate causal policy effects. Higher home care allowance supplements have an income effect and a substitution effect. The income effect implies longer and the substitution effect shorter home care periods. However, in relation to the earnings potential of the mothers, the outcome is likely to differ (Burgess et al. 2008). Also, private day care supplements are likely to equalize the out-of-pocket costs of day care with public day care fees. Considering the forgone earnings when mothers stay out of the labor force, higher private day care supplements are more likely to have employment effects for mothers with higher earnings potential (Kornstad and Thoresen 2007).

Municipal supplements are more likely to be available in larger municipalities and in municipalities where the number of small children is relatively high, the number of people moving in is high, and the municipal tax rate is somewhat lower. Furthermore, since the municipality is responsible for providing public day care, the municipality is more likely to offer municipal supplements if the supply of public day care is insufficient (Miettunen 2008; Lahtinen and Selkee 2016).

\section{Data}

Our data set consists of a $60 \%$ random sample of all Finnish women giving birth between 2001 and 2009. The data set is compiled in cooperation between Statistics Finland and the Social Insurance Institution of Finland (Kela), based on their registers. The data set includes information on typical individual characteristics such as age, education, wages, and other income sources. Information on maternity, paternity and parental leave benefits, child home care allowances, and private day care allowances paid to mothers and their spouses are also available. The mothers' maternity and parental leave as well as employment, unemployment, and child home care allowance spells, with exact dates, are used to follow mothers after they give birth. It

\footnotetext{
${ }^{6}$ The take-up rate of private day care has been low in Finland, but is increasing. In 2000, the Social Insurance Institution of Finland granted private day care allowance for 3.7\% of children aged 9 months to 6 years. In 2010, the respective proportion was almost 5\% (Kela 2016). In 2000, 59.1\% of children aged 9 months to 6 years attended day care. In 2010, this proportion increased to $62.3 \%$. The proportion of children attending private day care of all children in day care was 7-8\% during this period (Kela 2016; Säkkinen and Kuoppala 2018).
} 
is possible to link information on household members; hence, information on married or cohabiting partners is also available.

Municipal supplements to home care allowance (HCA) and private day care allowance (PCA) vary between municipalities. During the research period, the number of municipalities that offer supplements has increased. In 2000, $23 \%$ of municipalities offered one or both of the supplements, and by 2012, the proportion had increased to 52\% (Räsänen et al. 2019). The municipalities decide upon the level and criteria for the supplements that can depend, for instance, on the age of the child or the number of children in the family. Municipalities can choose to administer the supplements themselves or commission the administration from Kela. During the research period, an increasing number of municipalities pay out their supplements through Kela. ${ }^{7}$ At the end of the research period, Kela administers more than half of the HCA supplements and around three quarters of the PCA supplements (Räsänen et al. 2019). The data set contains information on municipal supplements paid by Kela. Hence, mothers giving birth in municipalities that administer the supplements themselves are excluded from the analyses. ${ }^{8}$

In the analyses, we include mothers who are at least 19 years old, who have given single birth to their first or second child, have a living partner at childbirth, and live in a municipality that does not offer municipal supplements at all or administers them through Kela. These mothers are entitled to the same type of public support. We follow the mother until her child is 36 months old, so the youngest cohort is followed until 2012. Eligibility for HCA ends when the child turns three, as does the job protection period for mothers who were employed at the time of childbirth. Cases where the child has died within 36 months after childbirth are excluded from the analyses, and cases where the parents divorce or a new child is born into the family are censored from the analyses.

We have chosen to include first and second births in the analyses. The general fertility rate in the early 2000s increased from 1.73 in 2000 to 1.87 in 2010, and the average number of children per family is around 1.8 (Statistics Finland 2017). Analyzing first and second births covers the average number of children in families. Some mothers may have given birth to a third or fourth child within the studied period, but we exclude births of higher parities from the analyses.

We use the consumer price index to express monetary values in euros in the year 2000. The highest earnings from two years preceding the birth comprise the earnings measures for mothers and fathers. ${ }^{9}$ Most other characteristics of the mothers are measured when the child is born. Time-dependent variables make an exception: municipality, municipal unemployment rate, information whether partner is unemployed, and age-specific HCA and PCA benefits depending on the municipality of residence.

\footnotetext{
${ }^{7}$ See Table 4 in the Appendix for more information on the number of municipalities offering the supplements.

${ }^{8}$ Mothers living in municipalities that pay out the supplements through Kela are representative among mothers living in municipalities that pay out municipal supplements.

${ }^{9}$ The level of the family leave benefits are mostly based on taxable earnings 2 years prior to the birth, but if later earnings are higher, the benefit level is based on the more recent earnings.
} 
Tables 1 and 2 present descriptive statistics for mothers by municipal supplement type. Overall, most mothers giving birth to their first or second child are attached to the labor market and have at least secondary education. Around $10 \%$ of the mothers are employed before but not at the time of childbirth whereas $60 \%$ have an employment contract when the child is born. Around $30 \%$ of mother are students,

Table 1 Descriptive statistics for mothers, measured at or prior to childbirth, first child

\begin{tabular}{|c|c|c|c|c|c|}
\hline Variable & Category & No supplements & Only HCA & Only PCA & Both \\
\hline Age & & 27.3 & 27.2 & 27.9 & 29.3 \\
\hline \multirow[t]{3}{*}{ Education } & Basic & 0.123 & 0.125 & 0.125 & 0.134 \\
\hline & Secondary & 0.483 & 0.454 & 0.438 & 0.321 \\
\hline & Tertiary & 0.393 & 0.421 & 0.437 & 0.545 \\
\hline \multirow[t]{2}{*}{ Marital status } & Cohabiting & 0.536 & 0.524 & 0.501 & 0.419 \\
\hline & Married & 0.464 & 0.476 & 0.499 & 0.581 \\
\hline \multirow[t]{5}{*}{$\begin{array}{l}\text { Labor market status } \\
\text { before childbirth }\end{array}$} & $\begin{array}{l}\text { Employed at } \\
\text { childbirth }\end{array}$ & 0.565 & 0.576 & 0.616 & 0.689 \\
\hline & $\begin{array}{l}\text { Employed before } \\
\text { childbirth }\end{array}$ & 0.126 & 0.130 & 0.108 & 0.092 \\
\hline & Student & 0.064 & 0.063 & 0.062 & 0.043 \\
\hline & Unemployment & 0.132 & 0.131 & 0.109 & 0.064 \\
\hline & Other & 0.113 & 0.099 & 0.105 & 0.111 \\
\hline Emp. months within & & 8.4 & 8.8 & 8.8 & 9.4 \\
\hline 12 months before & & & & & \\
\hline 1st childbirth & & & & & \\
\hline \multirow[t]{2}{*}{ Immigrant } & No & 0.972 & 0.970 & 0.959 & 0.921 \\
\hline & Yes & 0.028 & 0.030 & 0.041 & 0.079 \\
\hline Wage & & 15,196 & 15,885 & 16,821 & 21,735 \\
\hline Spouses wage & & 22,652 & 23,247 & 24,163 & 30,528 \\
\hline \multirow{3}{*}{$\begin{array}{l}\text { Type of employer, } \\
\text { if employed at } t=0\end{array}$} & Private & 0.632 & 0.618 & 0.635 & 0.649 \\
\hline & Municipality & 0.308 & 0.322 & 0.281 & 0.226 \\
\hline & State & 0.060 & 0.060 & 0.084 & 0.126 \\
\hline Unemployed spouse & & 0.096 & 0.106 & 0.106 & 0.079 \\
\hline \multirow[t]{3}{*}{ Municipality type } & Urban & 0.217 & 0.813 & 0.779 & 0.977 \\
\hline & Semiurban & 0.285 & 0.005 & 0.164 & 0.022 \\
\hline & Rural & 0.498 & 0.182 & 0.056 & 0.002 \\
\hline Municipal unemp. rate & & 11.7 & 12.1 & 11.4 & 8.2 \\
\hline $\begin{array}{l}\text { HCA supplement, } \\
100 \text { eur/month }\end{array}$ & & 0 & 0.815 & 0 & 1.805 \\
\hline $\begin{array}{l}\text { PCA supplement, } \\
100 \text { eur/month }\end{array}$ & & 0 & 0 & 1.980 & 3.204 \\
\hline Unique mothers & & 23,819 & 2193 & 19,849 & 33,747 \\
\hline
\end{tabular}


Table 2 Descriptive statistics for mothers, measured at or prior to childbirth, second child

\begin{tabular}{|c|c|c|c|c|c|}
\hline Variable & Category & No supplements & Only HCA & Only PCA & Both \\
\hline Age & & 29.0 & 29.4 & 29.8 & 31.0 \\
\hline \multirow[t]{3}{*}{ Education } & Basic & 0.126 & 0.116 & 0.127 & 0.140 \\
\hline & Secondary & 0.474 & 0.440 & 0.409 & 0.308 \\
\hline & Tertiary & 0.400 & 0.445 & 0.464 & 0.552 \\
\hline \multirow[t]{2}{*}{ Marital status } & Cohabiting & 0.358 & 0.318 & 0.317 & 0.266 \\
\hline & Married & 0.642 & 0.682 & 0.683 & 0.734 \\
\hline $\begin{array}{l}\text { Age difference of 1st } \\
\text { and } 2 \text { nd child }\end{array}$ & & 31.021 & 33.824 & 31.995 & 32.179 \\
\hline \multirow[t]{5}{*}{$\begin{array}{l}\text { Labor market status } \\
\text { before childbirth }\end{array}$} & $\begin{array}{l}\text { Employed at } \\
\text { childbirth }\end{array}$ & 0.549 & 0.575 & 0.605 & 0.652 \\
\hline & $\begin{array}{l}\text { Employed before } \\
\text { childbirth }\end{array}$ & 0.121 & 0.106 & 0.104 & 0.086 \\
\hline & Student & 0.028 & 0.023 & 0.029 & 0.025 \\
\hline & Unemployment & 0.080 & 0.089 & 0.071 & 0.037 \\
\hline & Other & 0.221 & 0.206 & 0.190 & 0.200 \\
\hline $\begin{array}{l}\text { Emp. months within } \\
12 \text { months before } \\
1 \text { st childbirth }\end{array}$ & & 7.4 & 8.2 & 8.0 & 8.8 \\
\hline $\begin{array}{l}\text { Employment months } \\
\text { between childbirths }\end{array}$ & & 8.6 & 9.5 & 10.1 & 9.6 \\
\hline HCA take-up & & 0.473 & 0.482 & 0.411 & 0.431 \\
\hline \multirow[t]{2}{*}{ Immigrant } & No & 0.978 & 0.984 & 0.966 & 0.932 \\
\hline & Yes & 0.022 & 0.016 & 0.034 & 0.068 \\
\hline Wage & & 15,950 & 16,541 & 17,858 & 22,277 \\
\hline Spouses wage & & 26,856 & 28,821 & 29,730 & 37,831 \\
\hline \multirow{3}{*}{$\begin{array}{l}\text { Type of employer, } \\
\text { if employed at } t=0\end{array}$} & Private & 0.584 & 0.552 & 0.586 & 0.609 \\
\hline & Municipality & 0.359 & 0.395 & 0.330 & 0.253 \\
\hline & State & 0.057 & 0.053 & 0.084 & 0.138 \\
\hline Unemployed spouse & & 0.091 & 0.095 & 0.093 & 0.080 \\
\hline \multirow[t]{3}{*}{ Municipality type } & Urban & 0.164 & 0.787 & 0.735 & 0.964 \\
\hline & Semiurban & 0.310 & 0.008 & 0.191 & 0.034 \\
\hline & Rural & 0.526 & 0.205 & 0.074 & 0.002 \\
\hline Municipal unemp. rate & & 11.2 & 11.7 & 10.8 & 8.1 \\
\hline $\begin{array}{l}\text { HCA supplement, } \\
100 \text { eur/month }\end{array}$ & & 0 & 0.988 & 0 & 1.809 \\
\hline $\begin{array}{l}\text { PCA supplement, } \\
100 \text { eur/month }\end{array}$ & & 0 & 0 & 2.006 & 3.410 \\
\hline Unique mothers & & 14,719 & 1547 & 11,373 & 18,517 \\
\hline
\end{tabular}


unemployed, or outside the labor force before childbirth and are included in the category other.

Municipalities that offer both supplements are mainly urban, that is, larger cities where the unemployment rate is lower and private and state employers are somewhat over-represented. A majority of municipalities in rural areas offer neither supplement, and it is quite common for municipalities in semi-urban areas as well. Characteristics of mothers within different types of municipalities differ as well. It is more common in urban areas to give birth at an older age, have a higher education, and be employed than in rural areas. As regards second births, the mean age difference between the first and second child is somewhat over 30 months, and the mother has been employed around 9 months between childbirth. However, the means vary by municipal supplements offered.

\section{Empirical strategy}

To evaluate the effect that municipal supplements have on how mothers time their return to employment after childbirth-in line with the theoretical frameworks by Kornstad and Thoresen (2007) and Burgess et al. (2008)—we apply a Cox proportional hazard model. We choose the model instead of making assumptions about the distribution of return to employment, since the conditional employment hazard increases at the end of the follow-up period when the job protection period ends and the youngest child turns three.

The sample includes multiple treated municipalities, and the timing of the treatment varies. Municipal supplements are introduced and the levels of the supplements are altered over the years. To identify the causal effects of municipal supplements on the hazard function, we use the time-varying nature of both home care and private day care allowances, and allow the supplements to vary by the age of the child. We estimate the employment hazard, $h_{i}(j)$, with a baseline hazard, $H_{0 m}(j)$, stratified by municipality of residence, $m$, and explanatory variables:

$$
\log h_{i}(j)=\log H_{0 m}(j)+X_{i j m} \beta+\delta M_{j m}+Y E A R_{i} \gamma,
$$

where $i$ stands for individual, $j$ for age of child, and $m$ for municipality. Supplements $M_{j m}$ depend on year but, for clarity, we omit the subscript for time. $M_{j m}$ is the value of the allowance per month divided by 100 in municipality $m$ for child at age $j$. The coefficient $\delta$ measures the overall effect of the supplement on the log employment hazard, when the pre-birth characteristics of the mother, characteristics of her family and spouse, and the municipality are controlled for, all included in $X_{i j m}$. The allowance, $M$, is either home care allowance (HCA) or private day care allowance (PCA), measured at municipality level. ${ }^{10}$ The baseline hazard, $\log H_{0 m}(j)$, is allowed to vary between municipalities. Hence, the municipal fixed effects remove variation between municipalities, and the variable $Y E A R_{i}$ removes varying time effects or

\footnotetext{
${ }^{10}$ See Table 4 in the Appendix for more information on the number of municipalities offering the supplements and the mean supplement levels for different age groups.
} 
shocks. ${ }^{11}$ Birth month dummies are also included to remove the seasonality from the model. $^{12}$

We analyze how different levels of subsidies after the earnings-related parental leave period affect the timing of the return to employment. When the earnings-related parental leave ends, the flat rate HCA and PCA will be related to the mother's earnings potential and child-care costs. All families are entitled to public child care for the same fee nationwide. Hence, we omit the price for public day care from the estimation. Furthermore, all families are entitled to flat rate HCA and PCA. Hence, these policy instruments have no exogenous variation. The HCA and PCA supplements vary between municipalities, which we use as identification of policy effects.

We extend the model for HCA in several ways to test for the effects of the policy design. Firstly, we interact characteristics of the mother with the HCA supplement. Secondly, we estimate dynamic effects by allowing the coefficients to vary depending on the level of HCA in relation to the age of the child. We estimate $\delta_{j}$ (instead of $\delta$ ) and let the coefficient $\delta_{j}$ vary at interval boundaries when the age of the child is $j=9,12,18,24,30$. Thirdly, we interact the supplement with labor market status, measured before childbirth, and let the coefficient for the supplement, $\delta_{j}$, vary at interval boundaries.

Lastly, some municipalities pay higher supplements when the child is younger but discontinue payments or reduce the supplement level when the child turns 1.5 or 2 years old. To test whether reductions also affect use, we include interactions between dummy variables indicating that the municipality reduces the supplement when the child is 1.5 and/or 2 years old and the age of the child.

\section{Results}

\subsection{Average effects}

Theoretically, higher HCA should reduce the employment hazard while higher PCA should increase the employment hazard. Higher HCA increases the relative price of day care and at the same time reduces the opportunity cost and the relative price of home care. In comparison, higher PCA reduces the relative price of private day care with respect to public day care.

We start our main analysis by examining the overall impact of benefit levels on the duration of home care until the mothers return to employment after having their first or second child. The results are presented in Table 3. Overall, higher HCA

\footnotetext{
${ }^{11}$ Since treatments are clustered in municipalities, we use clustered standard errors by municipality, as suggested by Abadie et al. (2017). Removing fixed effects with dummy variables in Cox regression models leads to biased estimators. Removing fixed effects by stratification, renders approximately unbiased estimates (Allison 2009). Hence, we include municipal fixed effect by stratification. Since the number of observations per year is sufficient and the number of years is small, we include year dummies in the estimations.

${ }^{12}$ The most common ending month of home care allowance spells are between July and early fall, when children usually start in day care.
} 
Table 3 Coefficient estimates of the employment effect of supplements, first and second child

Dependent variable: Employment

First child Second child

(1)

(2)

Home care supplement, 100 euro/m

$\begin{array}{ll}-0.137^{* * *} & -0.130^{* * *} \\ (0.021) & (0.022)\end{array}$

Private care supplement, 100 euro/m

$-0.014$

$-0.009$

(0.009)

Unique mothers

79,608

46,156

Observations

228,874

144,458

Note: Specifications also include controls for individual and family characteristics, municipal unemployment, and municipal and year fixed effects (see Table 5)

Note: ${ }^{*} p<0.1 ;{ }^{* *} p<0.05 ;{ }^{* * *} p<0.01$

supplement levels increase the duration of home care. In a municipality with a 100euro higher supplement level, the employment hazard is reduced by $12-13 \%$, which translates to, on average, 2-3 months longer child-care leaves. A 100-euro higher monthly PCA supplement, on the other hand, is insignificant. The PCA supplement reduces the price difference between public and private day care. However, the outof-pocket price for private day care is hardly cheaper. Hence, most parents choose public day care. PCA increases child-care options but has no employment effects.

The propensity to use home care allowance varies by the characteristics of the mother, and the characteristics of the mother are also associated with the duration of home care. All coefficients in the above-mentioned estimates are shown in the Appendix, Table 5. The results are in line with previous research. Mothers with higher earnings potential and attachment to the labor market before childbirth return to employment sooner.

\subsection{Heterogeneous and dynamic effects}

The mean effect of HCA is significant and considerable, and we will now scrutinize the heterogeneous and dynamic effects of HCA. To investigate the heterogeneous effects, we estimate relative hazards by introducing interactions between the HCA supplement level and the characteristics of the mothers. The results are shown in Fig. 1. The general results show that higher HCA supplements extend the home care period and delay labor market return.

In the first row of the left panel, we find the relative hazards when the HCA supplement is 100 euros higher among different age groups. The younger the mother is, the more reactive she will be to a higher HCA supplement and the more likely she is to stay at home longer. 


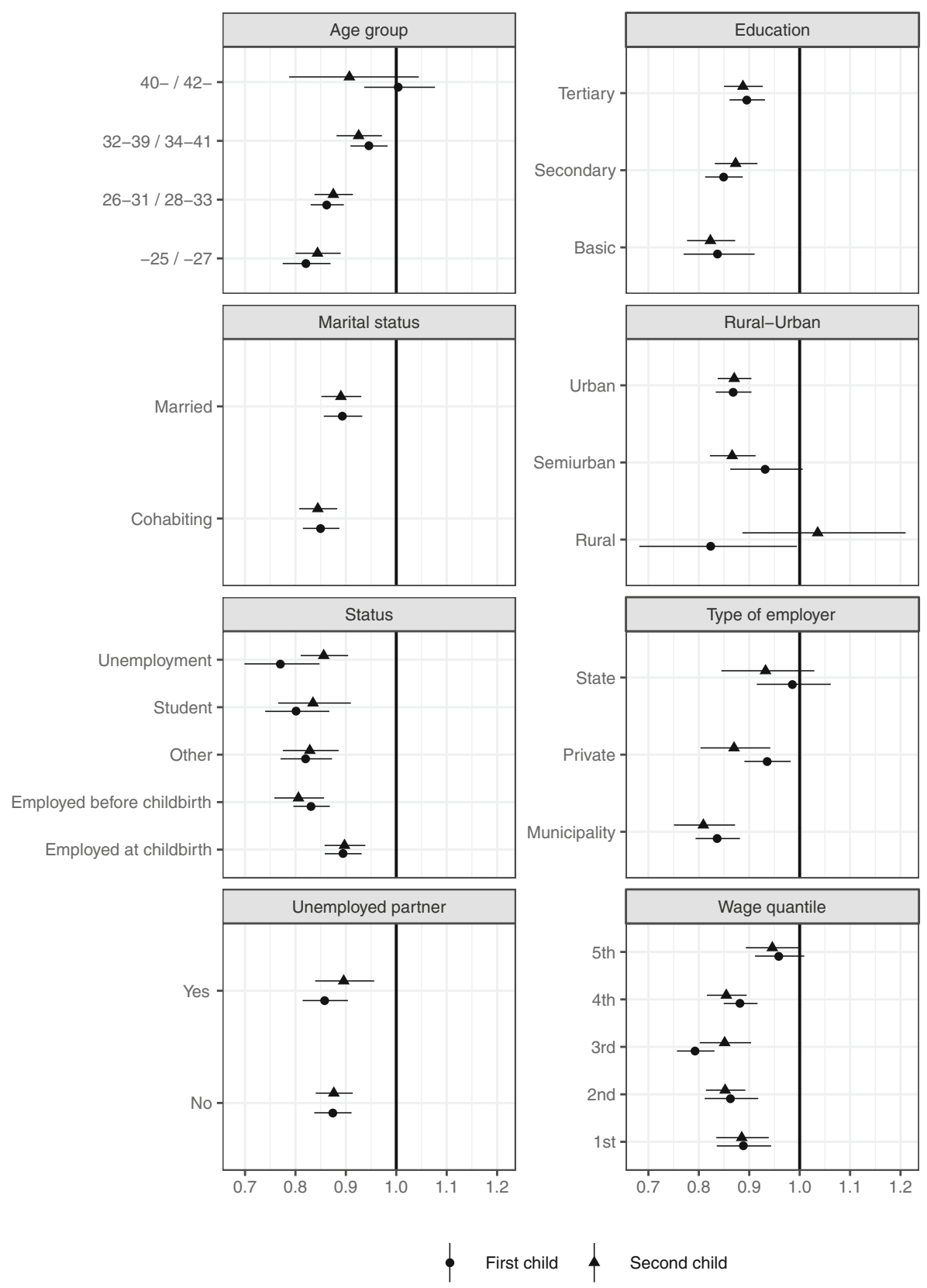

Fig. 1 Relative employment hazards among mothers with different characteristics when the municipal supplement to home care allowance is 100 euros higher. Note 1: The relative hazards for each group are estimated separately in a full model with interaction effects included respectively. The models are estimated with municipal fixed effects (except for rural-urban estimates), year fixed effects, and clustered standard errors by municipal level. In the model for the sector of the employer, only mothers employed at childbirth are included. Note 2: The horizontal lines indicate $95 \%$ confidence intervals 
In general, cohabiting mothers return sooner to the labor market than married mothers, but cohabiting mothers are more sensitive to a higher HCA supplement. The relative hazard rate is 5-6\% lower among cohabiting than among married mothers if the HCA is 100 euros higher. Cohabiting mothers need higher allowance levels to run the risk of prolonging home care. The general effect indicates that an unemployed partner increases the risk to return to employment. However, if the HCA supplement is higher, an unemployed partner has no significant effect different from an employed partner on the decision to return to employment.

Mothers with higher earnings potential generally return to the labor market sooner. On the first row of the right panel, we find relative hazard rates when the HCA supplement is 100 euros higher among mothers with different levels of education. These results confirm the general results. An increase of the HCA supplement delays labor market entry, but to a lesser extent among highly educated mothers. Considering earnings, mothers in the middle of the income distribution are likely to react more strongly to a higher HCA supplement, while mothers in the highest income quintile react the least, followed by mothers in the lowest income quintile. Mothers with high wages are not tempted to stay home for longer periods, even with higher HCA supplements. Mothers with low earnings may not afford to stay home for long periods, even if the HCA supplement is higher.

We also find that the impact of labor market status before childbirth is distinct. Mothers with an employment contract react less to a higher HCA supplement than mothers with all other statuses. The difference between mothers of first and second children is strongest among the unemployed and students.

For mothers employed at childbirth, we estimate the interaction effects by employer sector. A 100-euro higher HCA supplement level does not affect the timing of return to the labor market among mothers employed by the state. Those employed in the private sector postpone the return somewhat, especially with their second child. Mothers employed by municipalities react strongest. Typical female professions in municipalities are nurses and teachers which may explain the strong effect. These results indicate that women have chosen careers pre-birth that are family friendly or have other non-monetary job-characteristics, which are not easily identified with register data.

The impact of a higher HCA supplement level in different municipality types is shown in the second row of the right panel. Mothers in an urban municipality react the strongest, followed by mothers in semi-urban municipalities, where mothers of first children are less reactive than mothers of second children. In rural areas, mothers of first children react the strongest (but the confidence interval is wide) while mothers of second children are likely not to react to higher municipality supplements. The results are in line with the fact that the labor demand differs between municipality types.

A corresponding analysis of the heterogeneous effects of PCA gives few significant effects for different types of mothers. This is unsurprising as the main effect is insignificant and the proportion of children attending private day care of all children in day care was $7-8 \%$ during the research period. If higher PCA supplements have employment effects, the increase in the PCA supplement should increase the employment hazard of mothers with higher earnings potential. On average, private 


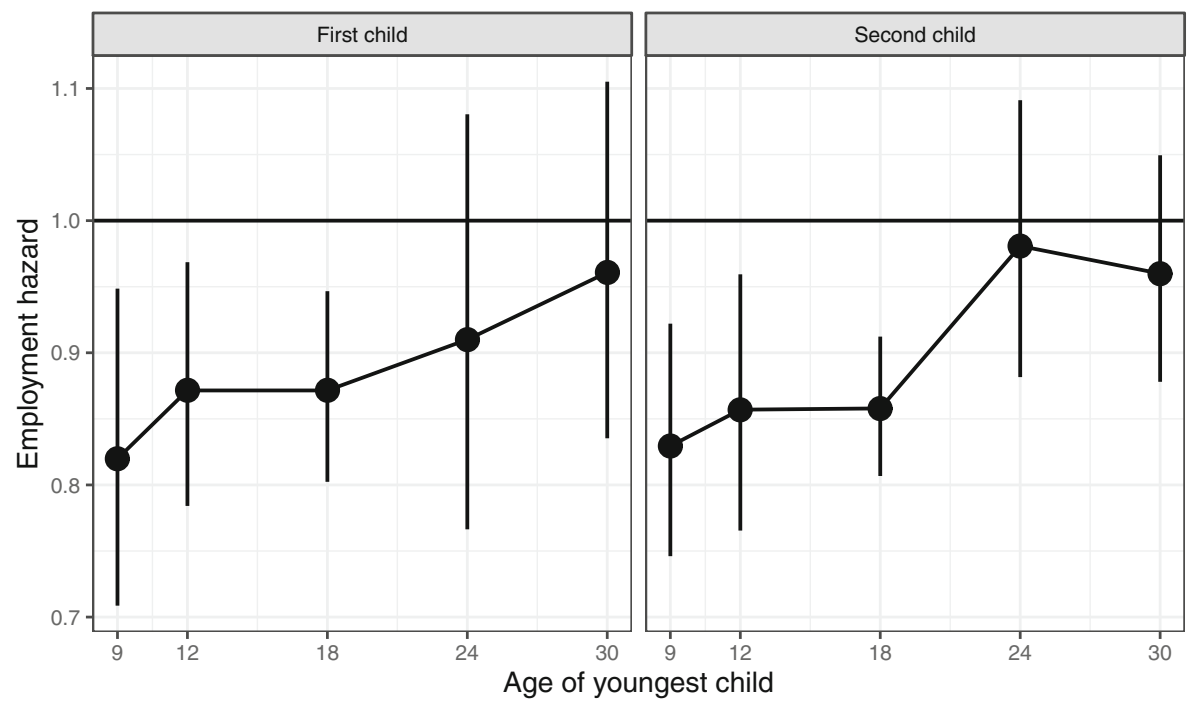

Fig. 2 Relative employment hazard among mothers with children at different ages, 9-36 months, when the municipal supplement to home care allowance is 100 euros higher, for the first child (left panel) and the second child (right panel). Note 1: The models are estimated with all controls, municipal and year fixed effects and clustered standard errors by municipal level. Note 2: The vertical lines indicate $95 \%$ confidence intervals

day care is more expensive than public day care for low-income families. For highincome families, there is only a small out-of-pocket price difference and they should be indifferent between private and public child care with respect to price. However, we do not identify increased employment hazards among mothers from any wage quintile when the PCA supplement is increased. ${ }^{13}$

By allowing the coefficients to vary by the age of the child, we find dynamic effects. The level of the HCA supplement in relation to the child's age affects the decision to return to the labor market. The results are presented in Fig. 2. The results are similar among first- and second-time mothers. If the HCA supplement is 100 euros higher close to the end of the parental leave, that is, when the child is 9 months old, the mother is more likely to continue with home care. The employment hazard is reduced by around $18 \%$. The effect diminishes somewhat when the child is $12-$ 18 months old, when the employment hazard is reduced by $13-14 \%$. Mothers who are at home with their child aged 2 years or older are unaffected by a higher HCA supplement. The employment hazard is still reduced when the child is $24-36$ months old but the confidence intervals are wide, indicating that there is considerable variation between socioeconomic background variables.

\footnotetext{
${ }^{13}$ These results are not shown here, but they are available upon request.
} 


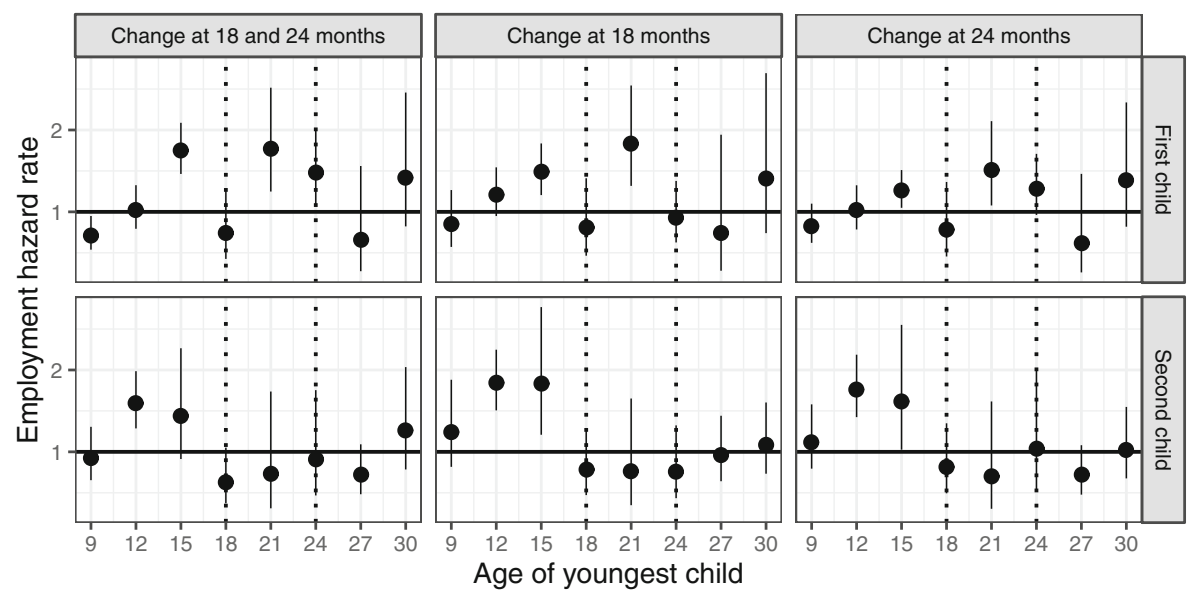

Fig. 3 Variations in employment hazard rates at different ages of the child, when the municipal home care allowance supplement is reduced when the child is 18 and/or 24 months (when controlling for the municipal home care allowance supplement). Note 1: The effects are estimated in a full model with the level of the supplement and dummies for reduction at age of child 18 and/or 24 months. The models are estimated with municipal and year fixed effects and clustered standard errors by municipal level. Note 2 : The vertical lines indicate $95 \%$ confidence intervals

We study this further and test whether the level of the HCA supplement varies by the labor market status of the mother before childbirth and whether the level of the HCA supplement varies by the age of the child by combining both heterogeneous and dynamic effects. The relative employment hazards for labor market status before childbirth when the HCA supplement is 100 euros higher are shown in Fig. 5 in the Appendix. The effect of a higher supplement level fades out for all mothers when the child is aged two or older, with some variations. The largest differences between groups with different labor market statuses are, in fact, found when the child is younger. Mothers attached to the labor market pre-birth are affected less than mothers who are less attached. This effect is more pronounced at first birth.

If mothers react to higher HCA supplement levels, they are also likely to react to a reduction of the supplement. The municipality can decide on the level of the supplement, and the level can depend on the age of the child. Potential reductions usually take place when the child is 18 and/or 24 months. ${ }^{14}$ Figure 3 presents the effects of a reduction of the municipal HCA supplement on the employment hazard. The upper panel shows the effects of the reduction on the employment hazard for the first child and the lower panel for the second child. The results show the effect of the reduction, since the level of the HCA supplement (before and after the reduction) is controlled for. Overall, reductions in the HCA supplement has implications for the timing of the return to employment. Mothers of first children are likely to use

\footnotetext{
${ }^{14}$ See Table 4 in the Appendix.
} 
higher HCA supplements and return to the labor market, or give birth to a second child before the supplement is reduced, in some cases with a short delay. Mothers of second children, on the other hand, are likely to use higher HCA supplements, but only for shorter periods until the child is 18 months old. In cases where a municipality reduces the HCA levels, we find an anticipation effect.

With reduced HCA supplement levels, mothers have several options. They can choose a longer home care period connected to the reduced subsidy levels and, hence, reduced consumption possibilities. An opposite choice is a short home care period connected to higher subsidy levels and increased consumption possibilities, especially when the mother returns to employment. By reducing HCA levels over time, it is possible to influence the length of the home care period. An interesting note is that less than a third of municipalities offering HCA supplements estimate the supplement to affect the demand for day care (Lahtinen and Selkee 2016). In that sense, few municipalities seem to believe their policy decisions influence the behavior of parents with small children.

When asked how long they would prefer to stay at home with their children, most parents of young children express a wish to extend the earnings-related parental leave period. Only one out of ten mothers and one out of five fathers were satisfied with the current length. A third of the mothers would prefer to extend earnings-related parental leave to 1.5 years, a quarter to 1 year, and another quarter to 2 years. Fathers are inclined to extend the earnings-related parental leave even longer. Almost a third would prefer the parental leave to be extended to 2 years, a quarter to 1.5 years, and $15 \%$ to 1 year (Salmi and Närvi 2017). The preferences expressed in the abovementioned survey are in line with our results regarding reactions to the timing of the change in the level of the HCA supplement. Mothers still at home when the child is 2 years old or older react neither to an increase nor to a decrease in the supplement level.

\subsection{Identification of causal effects}

The identification strategy uses changes in municipal supplements over the years. Some municipalities increase the supplement while others adopt a new supplement. The treatment group consists of mothers living in these municipalities. The control group consists of mothers living both in municipalities that do not offer municipal supplements and in municipalities that offer supplements but implement no changes. Both the number of municipalities as well as the average supplement levels vary by year and the age of the child. Table 4 in the Appendix presents the number of municipalities paying out supplements and the mean supplement levels for different age groups.

A causal identification requires, firstly, that actions by the mothers are not allowed to have any impact on the level of the supplement and that the policy implementations should be exogenous to the mothers. Hence, the decision by the municipality to increase the supplement should be uncorrelated with outcomes of the treated before the implementation. Secondly, differences between mothers receiving the increased 
municipal supplements and mothers in the control group should be stable over time. ${ }^{15}$ Moreover, treatment and control groups should follow common trends before the policy implementation. Lastly, there should be no spillover effects, which means that the control group has to be unaffected by the treatment. The last criterion is met, since the municipal supplements are available to residents only and mothers living in neighboring municipalities are ineligible for the supplement.

The first criterion for the identification strategy requires that mothers are unable to manipulate inclusion in the treatment group by fertility decisions, child spacing, or migration between control and treatment municipalities. ${ }^{16}$ However, the exact timing of childbirth, let alone conception, is something upon which future mothers cannot decide. Furthermore, home care allowance and private day care allowance supplements start when the child is about 9 months old. Hence, mothers' actions will have no immediate impact on the level of the supplement. Once the child is born, families may move to receive higher municipal supplements. ${ }^{17}$ However, that is unlikely as the payoff hardly covers the costs of moving. Hence, mothers' fertility decisions will have no immediate impact on the level of the supplement.

In addition, an increase in the supplement is uncorrelated with outcomes of the treated before the increase. Comparisons between treatment and control municipalities are presented in Table 8 in the Appendix. The results show that municipalities do not increase or implement the HCA supplement as a response to high demand for day care or high female labor force participation.

Regarding the second criterion, common trends among the treatment and the control group, our results are robust if employment decisions develop similarly before the supplement increase. Figures 6 and 7 in the Appendix show that the treated follow the same trend as control municipalities until the increase in supplement at

\footnotetext{
${ }^{15}$ To account for known differences between municipalities, we control for the municipal unemployment rate.

${ }^{16}$ To our knowledge, there is no causal evidence supporting the claim that higher supplements have effects on the timing and spacing of births in Finland. Rather, there has generally been a faster transition to have a second child birth in Finland in the late twentieth century. Berg and Rotkirch (2014) found that the average birth intervals have shortened between cohorts born in 1955 and 1975. They argue that higher age at first birth is associated with shorter birth intervals. They did not specifically test for the impact of the introduction of HCA, but their results indicate that the shortening of birth intervals happened mainly before the introduction of HCA. On the other hand, Erlandsson (2017) found that mothers using HCA with their first or second child are more likely to receive a subsequent child faster than those not using HCA. However, the analysis can not be interpreted as causal, since the results most likely reflect selection of family preferences among mothers. However, Aalto (2018) found that labor force participation among mothers was reduced when a speed premium was introduced in 2005, but found no effect on the timing of births.

${ }^{17}$ In the sample, $6.6 \%$ of mothers who have received their first child have moved to another municipality during pregnancy or before the child turns 9 months old. Only $0.6 \%$ have moved from a municipality that does not pay home care allowance supplement to a municipality that does. Only $0.7 \%$ have moved from a municipality that does not pay private day care supplement to a municipality that does. When the child is $9-36$ months old, the corresponding numbers are: $5.8 \%$ of mothers move to another municipality; $0.6 \%$ are HCA movers and $0.7 \%$ are PCA movers.
} 
year $t=0$. The employment hazard is unaffected by increases in the PCA supplement while increases in the HCA supplement reduce the employment hazard. Furthermore, the common trends assumption holds for subgroups of mothers as well. The results for subgroups of mothers with different labor market statuses before childbirth are shown in the Appendix, in Tables 6 for the first and Table 7 for the second child.

\section{Conclusions}

In the main analyses, support for private day care has insignificant effects on female labor force participation. This is unsurprising, since all children under school-age are entitled to public day care, which most families use. Instead, the PCA supplements increase the child-care options when the mother has decided to return to employment. These findings are in line with Viitanen (2011), who found no employment effects of private day care vouchers.

Support for home care, on the other hand, has significant effects on the decision to return to employment after childbirth. Mothers assume the lion's share of the responsibility for early child care, and the level of the HCA affects the duration of home care. A 100-euro higher HCA supplement level reduces the employment hazard by more than $12 \%$. During the research period, mothers of first children stay home with their child for an average of 23 months and mothers of second children for an average of 24 months, including the earnings-related maternity and parental leave period in addition to HCA. A 100-euro higher HCA supplement level prolongs the home care period by an average of 3 months for first-time mothers and 2 months for second-time mothers.

The mean municipal HCA supplement during the research period varies between 120 and 160 euros per month. In a municipality with an average supplement level, mothers are likely to stay home for 2-5-months longer with their child(ren) compared to mothers in municipalities without supplements. This can be considered a relatively small difference on the individual level. However, for every 10,000 first and second births this translates into approximately 1600 to 4200 additional years of home care of children instead of employment years.

We contribute to the literature by offering both contrasting and new evidence on heterogeneous and dynamic effects of child care benefits. In contrast to the analyses by Burgess et al. (2008), the mothers in our sample are entitled to the same rights and can choose between home care and day care for children up to 3 years of age. We use municipal variation in HCA supplement levels and find support for causal effects on the duration of home care. Concerning average employment effects, previous Finnish results show that a 100-euro higher HCA supplement level reduces female labor force participation by an average of 3\% (Kosonen 2014; Kosonen and Huttunen 2018). Our results on average effects confirm this and point out mechanisms behind the relationship. Higher HCA supplements increase the length of home care periods, which in turn reduces labor force participation. Additionally, varying replacement 
rates combined with different background characteristics affect the decision to return to employment after childbirth.

We find heterogeneous and dynamic effects similar to Kuhlenkasper and Kauermann (2010) and Fitzenberger et al. (2013) who use data from Germany where mothers can choose to take care of their children up to 3 years as well. We find more profound effects. Lower labor market attachment and earnings potential pre-birth delay the return to employment when mothers have a choice between home care and day care. The income effect dominates the substitution effect of the HCA, and the HCA supplement, for mothers with low earnings potential.

In addition, our results show that the impact of the supplement level depends on the age of the child. The impact of the introduction of higher supplement levels diminish when the child becomes older and has no effect when the child turns two. The impact of reductions in the supplement levels, on the other hand, stimulates a faster return to employment, but the effect does not correspond completely with the timing of the reduction. Burgess et al. (2008) predict that reduced benefit levels imply clustering in return to employment at that point. We observe that mothers either anticipate the decrease - the employment hazard increases before the decrease-or mothers react to the decrease with delay - the employment hazard increases with a short delay in some cases.

Our results have quite general policy implications applicable to other countries, as well. When mothers can choose between home care and child care and both choices are publicly supported, the level of the allowance impacts the length of home care and time away from employment. We know that the availability of long child-care leaves prolongs the time away from the labor force. However, higher reimbursement levels have different effects for different types of mothers. These heterogeneous effects can have detrimental impacts on the return to employment among women less attached to the labor market pre-birth. If the risk for human capital deterioration increases by the length of the home care period (as suggested by Cukrowska-Torzewska and Matysiak (2020)), mothers who are weakly attached to the labor market pre-birth may have increased difficulties in returning to the labor market after the home care period.

By increasing or reducing the reimbursement level, it is possible to influence the length of the home care period. Our results imply that the level of public support for home care has a significant impact until the child is around 2 years old. Public support for home care until the child turns three is suboptimal. Shorter periods are also more in line with a dual-earner model. Furthermore, longer support periods imply unambiguous policy effects.

Different families have different preferences and opportunity costs. If opportunity costs vary by the age of the child, the outcomes vary over time. Hence, policy effects do not only depend on individual and family characteristics but also on the age of the child. When designing new family policies, the heterogenous and dynamic effects should be taken into account. By focusing on average effects only, important policy implications are concealed. 


\section{Appendix A: More detailed results}

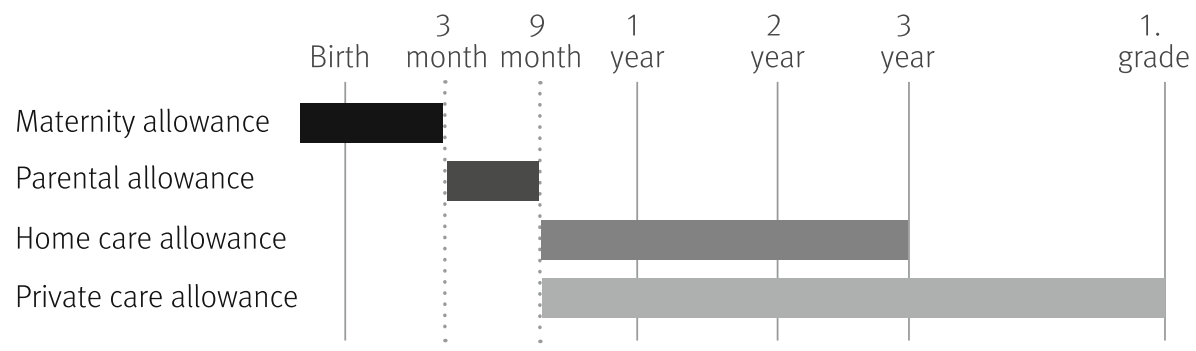

Fig. 4 Support to families. Note 1: Maternity leave (105 working days, ca. 4 months) starts 30-50 days before expected delivery. Mothers who have lived for 180 days in Finland and have been pregnant for at least 154 days are entitled to maternity leave. Note 2: Parental leave (158 working days, ca. 6 months) can be shared between the mother and the father. Note 3: Maternity and parental leave allowance have a general coverage rate of $70 \%$ of previous earnings up to a ceiling. The first threshold is above the mean earnings among women, after which the coverage rate is reduced for the exceeding part, above the first threshold to $40 \%$ and above the second threshold to $25 \%$. The thresholds are adjusted yearly. Some collective bargaining agreements require employers to pay full wages to the mother or the father during (a small) part of the maternal or parental leave. If the parent has no previous earnings, they receive a minimum reimbursement level, which is adjusted yearly. During the research period, 13.7-27.7\% of parental leave beneficiaries received the minimum reimbursement level. The variation in the shares is related to the business cycle. On average, mothers received 31 euros per day in 2000, which increased gradually to 47 in 2012. The corresponding daily reimbursements for fathers increased from 49 to 66 during the same period. These numbers are at 2000 prices (Kela 2013). Note 4: Home care allowance until the youngest child turns three. Flat rate allowance (on average 352 euros/family and month in 2000, and 321 euros/family and month in 2012, at 2000 prices (Kela 2013)) with some municipal supplements, see Table 4. Note 5: Private day care allowance for pre-school children. Flat rate allowance (on average 171 euros/month in 2000 and 172 euros/month in 2012, at 2000 prices (Kela 2013)) with some municipal supplements, see Table 4

Table 4 Average supplements and number of municipalities administering home care allowance (HCA) and private day care allowance (PCA) supplements through Kela by age of child

\begin{tabular}{|c|c|c|c|c|c|c|c|c|}
\hline \multirow[t]{2}{*}{ Year } & \multicolumn{3}{|c|}{ HCA, N } & \multicolumn{3}{|c|}{ HCA, Mean } & \multirow{2}{*}{$\begin{array}{l}\text { PCA, N } \\
9-35\end{array}$} & \multirow{2}{*}{$\begin{array}{l}\text { PCA, Mean } \\
9-35\end{array}$} \\
\hline & $9-17$ & $18-23$ & $24-35$ & $9-17$ & $18-23$ & $24-35$ & & \\
\hline 2000 & 6 & 6 & 5 & 162.86 & 162.86 & 134.89 & 53 & 158.99 \\
\hline 2001 & 9 & 9 & 9 & 142.29 & 142.29 & 118.61 & 59 & 164.81 \\
\hline 2002 & 10 & 10 & 9 & 151.82 & 151.82 & 118.48 & 58 & 166.85 \\
\hline 2003 & 11 & 11 & 10 & 142.96 & 142.96 & 112.46 & 64 & 171.25 \\
\hline 2004 & 14 & 14 & 13 & 131.55 & 131.55 & 107.27 & 64 & 176.27 \\
\hline 2005 & 16 & 16 & 13 & 126.61 & 126.61 & 108.95 & 66 & 177.67 \\
\hline 2006 & 17 & 17 & 12 & 120.65 & 117.76 & 112.02 & 68 & 179.75 \\
\hline 2007 & 17 & 17 & 10 & 121.15 & 118.34 & 112.63 & 70 & 190.64 \\
\hline 2008 & 28 & 26 & 16 & 119.63 & 118.83 & 113.73 & 69 & 214.09 \\
\hline 2009 & 34 & 32 & 21 & 132.11 & 132.23 & 132.6 & 70 & 252.2 \\
\hline 2010 & 41 & 39 & 27 & 130.8 & 131.67 & 130.62 & 74 & 260.5 \\
\hline 2011 & 53 & 51 & 38 & 128.32 & 128.07 & 121.59 & 75 & 262.74 \\
\hline 2012 & 56 & 54 & 41 & 126.17 & 125.99 & 120.6 & 81 & 274.46 \\
\hline 2013 & 49 & 47 & 38 & 125.16 & 124.22 & 119.97 & 77 & 278.09 \\
\hline
\end{tabular}

Note: Supplement values in year 2000 prices 
Table 5 Coefficient estimates of the employment effect of supplements, first (1) and second (2) child

\begin{tabular}{|c|c|c|}
\hline & (1) & (2) \\
\hline Home care supplement, 100 euro/m & $\begin{array}{l}-0.137^{* * *} \\
(0.021)\end{array}$ & $\begin{array}{l}-0.130^{* * *} \\
(0.022)\end{array}$ \\
\hline Private care supplement, 100 euro/m & $\begin{array}{l}-0.014 \\
(0.009)\end{array}$ & $\begin{array}{l}-0.009 \\
(0.010)\end{array}$ \\
\hline Education: secondary (ref = Basic) & $\begin{array}{l}0.166^{* * *} \\
(0.019)\end{array}$ & $\begin{array}{l}0.042^{*} \\
(0.024)\end{array}$ \\
\hline Education: tertiary & $\begin{array}{l}0.434^{* * *} \\
(0.023)\end{array}$ & $\begin{array}{l}0.166^{* * * *} \\
(0.027)\end{array}$ \\
\hline Age & $\begin{array}{l}-0.011 \\
(0.010)\end{array}$ & $\begin{array}{l}-0.044^{\text {*** }} \\
(0.013)\end{array}$ \\
\hline Age squared / 100 & $\begin{array}{l}-0.020 \\
(0.019)\end{array}$ & $\begin{array}{l}0.036^{*} \\
(0.022)\end{array}$ \\
\hline Married (ref = cohabitation) & $\begin{array}{l}-0.102^{* * *} \\
(0.011)\end{array}$ & $\begin{array}{l}-0.038^{* * *} \\
(0.013)\end{array}$ \\
\hline Log wage & $\begin{array}{l}0.148^{* * *} \\
(0.009)\end{array}$ & $\begin{array}{l}0.150^{* * * *} \\
(0.007)\end{array}$ \\
\hline Log partners wage & $\begin{array}{l}0.013^{* * *} \\
(0.002)\end{array}$ & $\begin{array}{l}0.015^{* * *} \\
(0.004)\end{array}$ \\
\hline Emp. months within 12 months before 1 st childbirth & $\begin{array}{l}0.038^{* * *} \\
(0.003)\end{array}$ & $\begin{array}{l}-0.003^{* *} \\
(0.002)\end{array}$ \\
\hline Employed before childbirth ( $\mathrm{ref}=$ at childbirth) & $\begin{array}{l}-0.170^{* * *} \\
(0.022)\end{array}$ & $\begin{array}{l}-0.044 \\
(0.033)\end{array}$ \\
\hline Other & $\begin{array}{l}-0.566^{* * *} \\
(0.039)\end{array}$ & $\begin{array}{l}-0.559^{\text {*** }} \\
(0.022)\end{array}$ \\
\hline Student & $\begin{array}{l}-0.075^{* *} \\
(0.030)\end{array}$ & $\begin{array}{l}-0.007 \\
(0.043)\end{array}$ \\
\hline Unemployed & $\begin{array}{l}-0.395^{* * *} \\
(0.028)\end{array}$ & $\begin{array}{l}-0.230^{\text {*** }} \\
(0.026)\end{array}$ \\
\hline Unemployed partner $($ yes $=1)$ & $\begin{array}{l}0.040 \\
(0.025)\end{array}$ & $\begin{array}{l}0.043^{* *} \\
(0.021)\end{array}$ \\
\hline Municipal unemp. rate & $\begin{array}{l}-0.007 \\
(0.005)\end{array}$ & $\begin{array}{l}-0.006 \\
(0.009)\end{array}$ \\
\hline Employment months between childbirths & & $\begin{array}{l}0.046^{* * *} \\
(0.001)\end{array}$ \\
\hline Age difference of 1 st and 2 nd child & & $\begin{array}{l}-0.042^{\text {*** }} \\
(0.001)\end{array}$ \\
\hline Used HCA before 2 nd child (yes $=1$ ) & & $\begin{array}{l}-0.512^{\text {*** }} \\
(0.015)\end{array}$ \\
\hline Unique mothers & 79,608 & 46,156 \\
\hline Observations & 228,874 & 144,458 \\
\hline
\end{tabular}

Note: Specifications also include birth month, nationality, and municipal and year fixed effects Note: ${ }^{*} p<0.1 ;{ }^{* *} p<0.05 ;{ }^{* * *} p<0.01$ 

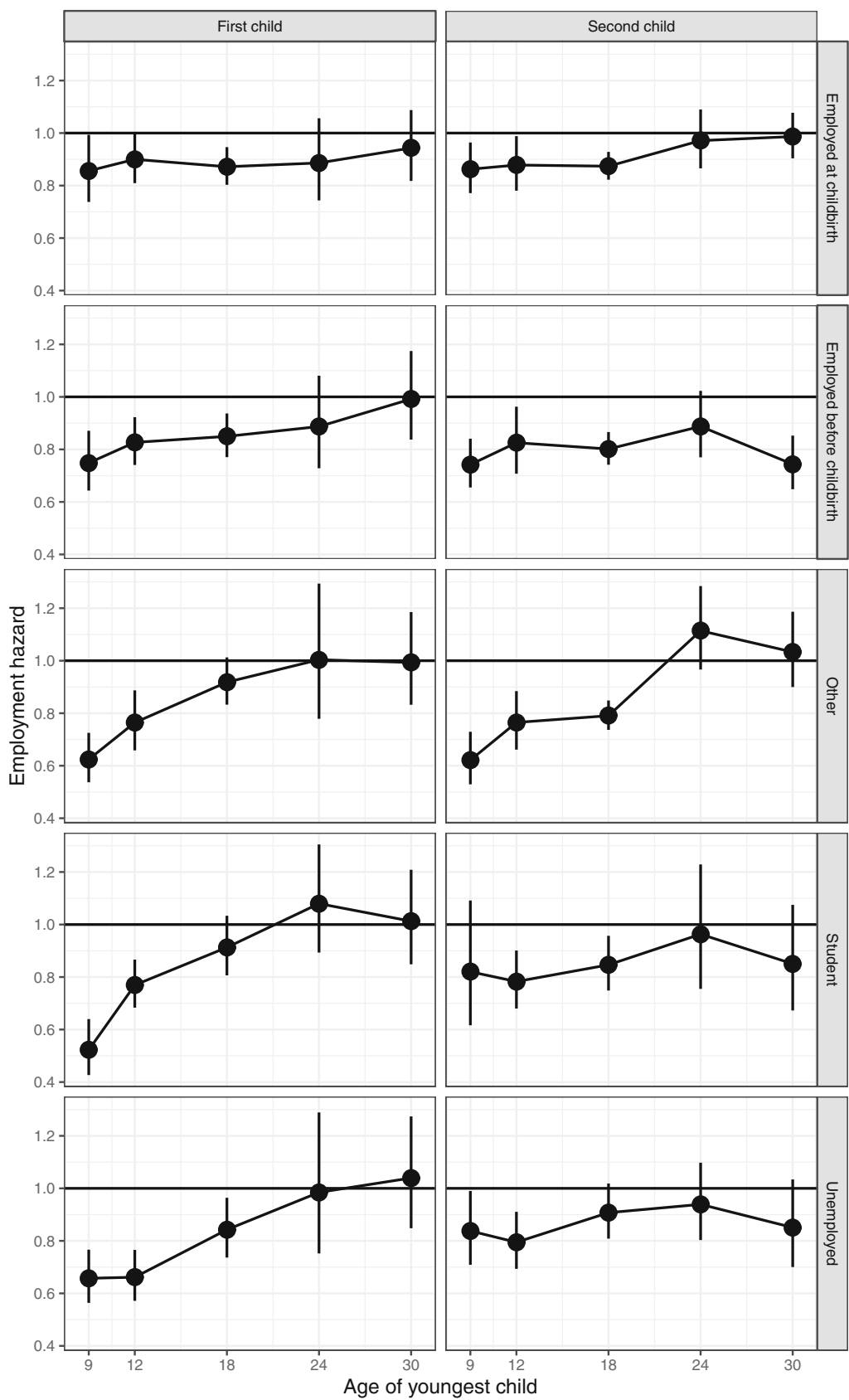

Fig. 5 Relative employment hazards among mothers with different labor market statuses before childbirth when the municipal supplement to home care allowance is 100 euros higher at ages 9-36 months of the first child (left panel) and the second child (right panel) Note 1: The employment hazards for each group are estimated separately in a full model with interaction effects included respectively. The models are estimated with municipal and year fixed effects and clustered standard errors by municipal level. Note 2 : The vertical lines indicate $95 \%$ confidence intervals 


\section{Appendix B: Identification tests}

\section{B.1 Counterfactual trends}

We test for counterfactual trends in treatment and control groups by including leads and lags in Eq. 1. We estimate the model for HCA and PCA supplements separately. We check supplement eligibility at the start of every interval when the child is 12 and 24 months old $(j=12,24)$. For instance, if the supplement increases by 100 euros when the child's age is within an interval, the increase is defined to take place. We check for possible effects 1-3 years prior, the year the increase is implemented, and 1-3 years after the increase. Figures 6 and 7 show the results. The common trends assumption also holds for the subgroups of mothers in Table 6 for the first child and Table 7 for the second child. The employment duration is generally unaffected before childbirth, and the hazard to return to employment is reduced when the supplement increases and the subsequent years.

\section{B.2 Municipal background characteristics}

If the municipalities respond to, for example, high female employment rates or excess demand for day care by increasing the HCA supplement, the policy effect is endogenous and the causal interpretation is invalid. We test if municipal background characteristics in the pre-treatment period before the increase are correlated with the
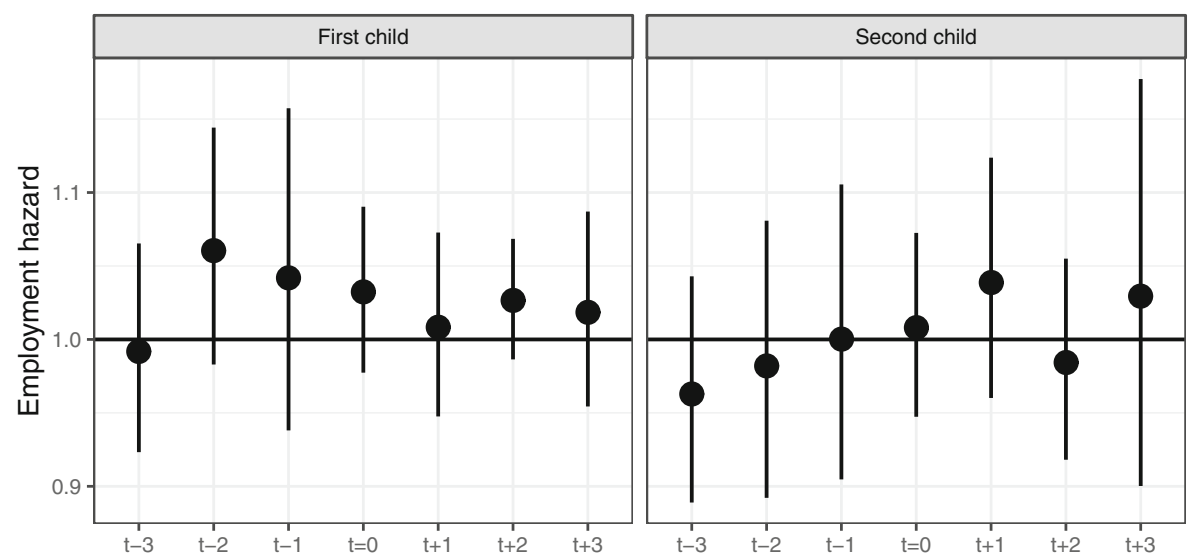

Fig. 6 Employment hazard among women giving birth of an at least 100-euro increase of the municipal supplement to the private day care allowance 1-3 years before, during, and 1-3 years after the increase, when the child is 12-36 months old. Note 1: The models are estimated with all control variables, municipal and year fixed effects, and clustered standard errors on municipal level. Note 2: The vertical lines indicate 95\% confidence intervals, and the reference category is no change or no supplement 

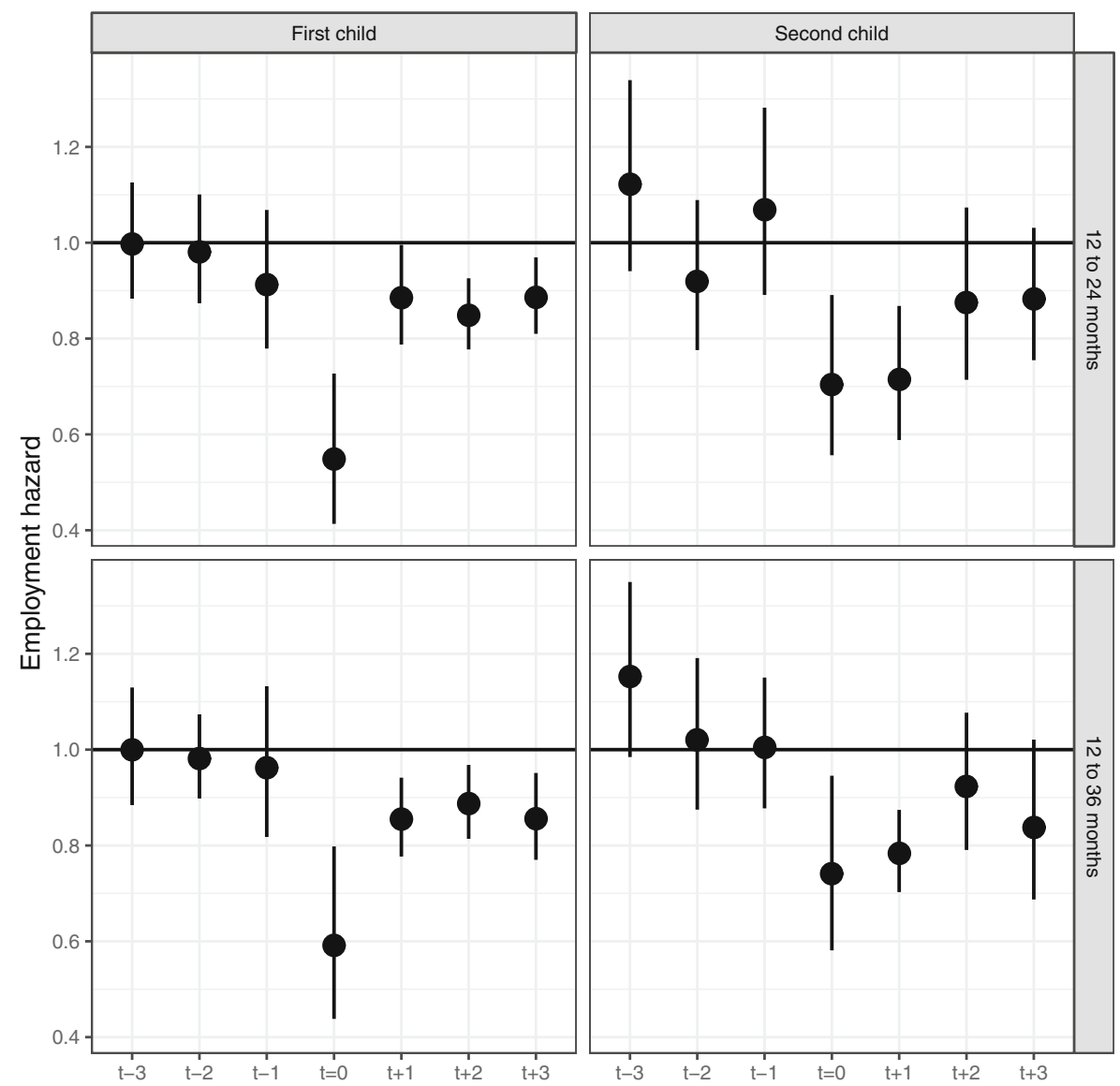

Fig. 7 Employment hazard among women giving birth of an at least 100-euro increase of the municipal supplement to home care allowance 1-3 years before, during, and 1-3 years after the increase: for children aged 12-24 months (the upper panel) and for children aged 12-36 months (the lower panel). Note 1: The models are estimated with all control variables, municipal and year fixed effects, and clustered standard errors on municipal level. Note 2 : The vertical lines indicate $95 \%$ confidence intervals, and the reference category is no change or no supplement

municipality increasing the supplement in year $t=0$. First, we aggregate the data to a balanced panel by municipality and year. Next, we estimate whether selected outcomes have changed before and after the increase of the HCA supplement. The selected outcome variables are the use of home care, public day care, and private day care, and furthermore, the employment rate of women with small children aged 0 to 6 . Table 8 shows that characteristics of treatment municipalities, municipalities 
Table 6 Coefficient estimates of the employment effect of a 100-euro increase of the HCA supplement, first child

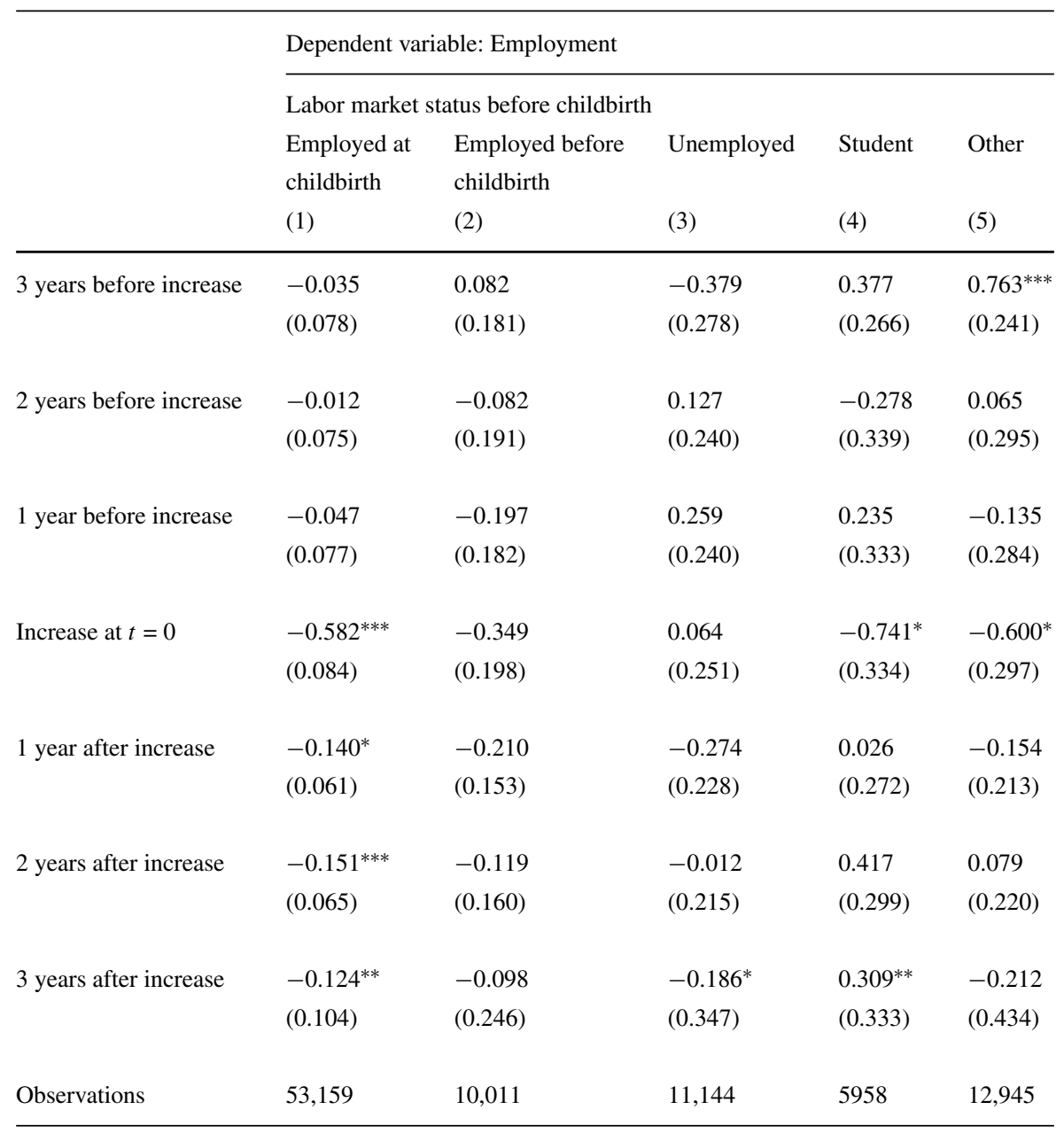

Note: Specifications include all controls, and municipal and year fixed effects

Note: ${ }^{*} p<0.05 ;{ }^{* *} p<0.01 ;{ }^{* * *} p<0.001$

that increase the home care supplement at $t=0$, do not deviate from control municipalities in the pre-treatment period from $t-4$ to $t-1$ year before the increase. In summary, increases are exogenous to the mothers. Additionally, municipalities increasing the supplement are representative among all municipalities in Finland in the pre-treatment period. 
Table 7 Coefficient estimates of the employment effect of a 100-euro increase of the HCA, second child

Dependent variable: Employment

Labor market status before childbirth

Employed at Employed before Unemployed Student Other childbirth childbirth

(1)

(2)

(3)

(4)

(5)

\begin{tabular}{|c|c|c|c|c|c|}
\hline 3 years before increase & $\begin{array}{l}0.201^{*} \\
(0.098)\end{array}$ & $\begin{array}{l}-0.060 \\
(0.229)\end{array}$ & $\begin{array}{l}0.204 \\
(0.291)\end{array}$ & $\begin{array}{l}0.258 \\
(0.539)\end{array}$ & $\begin{array}{l}0.092 \\
(0.210)\end{array}$ \\
\hline 2 years before increase & $\begin{array}{l}0.013 \\
(0.092)\end{array}$ & $\begin{array}{l}-0.042 \\
(0.235)\end{array}$ & $\begin{array}{l}0.101 \\
(0.321)\end{array}$ & $\begin{array}{l}1.087^{* * *} \\
(0.460)\end{array}$ & $\begin{array}{l}0.103 \\
(0.205)\end{array}$ \\
\hline 1 year before increase & $\begin{array}{l}-0.004 \\
(0.092)\end{array}$ & $\begin{array}{l}0.274 \\
(0.207)\end{array}$ & $\begin{array}{l}0.076 \\
(0.306)\end{array}$ & $\begin{array}{l}0.144 \\
(0.583)\end{array}$ & $\begin{array}{l}-0.438 \\
(0.247)\end{array}$ \\
\hline Increase at $t=0$ & $\begin{array}{l}-0.298^{*} \\
(0.089)\end{array}$ & $\begin{array}{l}-0.252 \\
(0.217)\end{array}$ & $\begin{array}{l}-0.961^{*} \\
(0.417)\end{array}$ & $\begin{array}{l}-0.281 \\
(0.492)\end{array}$ & $\begin{array}{l}-0.277 \\
(0.202)\end{array}$ \\
\hline 1 year after increase & $\begin{array}{l}-0.232^{*} \\
(0.075)\end{array}$ & $\begin{array}{l}-0.147 \\
(0.186)\end{array}$ & $\begin{array}{l}-0.218 \\
(0.253)\end{array}$ & $\begin{array}{l}-0.657^{* *} \\
(0.494)\end{array}$ & $\begin{array}{l}-0.506^{*} \\
(0.190)\end{array}$ \\
\hline 2 years after increase & $\begin{array}{l}-0.031 \\
(0.074)\end{array}$ & $\begin{array}{l}-0.145 \\
(0.190)\end{array}$ & $\begin{array}{l}0.083 \\
(0.246)\end{array}$ & $\begin{array}{l}-0.779 \\
(0.575)\end{array}$ & $\begin{array}{l}-0.336 \\
(0.182)\end{array}$ \\
\hline 3 years after increase & $\begin{array}{l}-0.246 \\
(0.127)\end{array}$ & $\begin{array}{l}0.234 \\
(0.257)\end{array}$ & $\begin{array}{l}-0.016 \\
(0.396)\end{array}$ & $\begin{array}{l}-0.312^{*} \\
(0.533)\end{array}$ & $\begin{array}{l}-0.450^{* *} \\
(0.298)\end{array}$ \\
\hline Observations & 32,384 & 5846 & 3940 & 1689 & 15,189 \\
\hline
\end{tabular}

Note: Specifications include all controls, and municipal and year fixed effects

Note: ${ }^{*} p<0.05 ;{ }^{* *} p<0.01 ;{ }^{* * *} p<0.001$ 
Table 8 OLS estimates for changes in main outcome variables, 1-4 years before and after an increase of the HCA supplement

Outcome variable:

\begin{tabular}{lllll}
\hline Home care & Public day & F. Employment & F. Employment & Private day \\
& care & $(0-6 y)$ & $(0-3 y)$ & care
\end{tabular}

(1) (2) (3) (4) (5)

\begin{tabular}{|c|c|c|c|c|c|}
\hline 4 years before increase & $\begin{array}{l}-0.008 \\
(0.008)\end{array}$ & $\begin{array}{l}0.008 \\
(0.008)\end{array}$ & $\begin{array}{l}0.009 \\
(0.010)\end{array}$ & $\begin{array}{l}0.004 \\
(0.011)\end{array}$ & $\begin{array}{l}-0.002 \\
(0.002)\end{array}$ \\
\hline 3 years before increase & $\begin{array}{l}-0.004 \\
(0.007)\end{array}$ & $\begin{array}{l}0.011 \\
(0.007)\end{array}$ & $\begin{array}{l}0.010 \\
(0.009)\end{array}$ & $\begin{array}{l}0.021^{*} \\
(0.012)\end{array}$ & $\begin{array}{l}-0.002 \\
(0.003)\end{array}$ \\
\hline 2 years before increase & $\begin{array}{l}-0.005 \\
(0.006)\end{array}$ & $\begin{array}{l}0.006 \\
(0.007)\end{array}$ & $\begin{array}{l}0.007 \\
(0.007)\end{array}$ & $\begin{array}{l}0.008 \\
(0.011)\end{array}$ & $\begin{array}{l}-0.0005 \\
(0.002)\end{array}$ \\
\hline 1 year before increase & $\begin{array}{l}0.012^{*} \\
(0.007)\end{array}$ & $\begin{array}{l}-0.007 \\
(0.008)\end{array}$ & $\begin{array}{l}0.005 \\
(0.009)\end{array}$ & $\begin{array}{l}0.003 \\
(0.012)\end{array}$ & $\begin{array}{l}-0.004 \\
(0.003)\end{array}$ \\
\hline Increase at $t=0$ & $\begin{array}{l}0.036^{\text {*** }} \\
(0.009)\end{array}$ & $\begin{array}{l}-0.026^{* *} \\
(0.010)\end{array}$ & $\begin{array}{l}-0.029^{* * *} \\
(0.010)\end{array}$ & $\begin{array}{l}-0.023^{*} \\
(0.013)\end{array}$ & $\begin{array}{l}-0.008^{* *} \\
(0.004)\end{array}$ \\
\hline 1 year after increase & $\begin{array}{l}0.029^{*} \\
(0.016)\end{array}$ & $\begin{array}{l}-0.012 \\
(0.017)\end{array}$ & $\begin{array}{l}-0.019 \\
(0.018)\end{array}$ & $\begin{array}{l}-0.042^{* *} \\
(0.020)\end{array}$ & $\begin{array}{l}-0.014^{* *} \\
(0.006)\end{array}$ \\
\hline 2 years after increase & $\begin{array}{l}0.032^{*} \\
(0.018)\end{array}$ & $\begin{array}{l}-0.020 \\
(0.018)\end{array}$ & $\begin{array}{l}-0.011 \\
(0.020)\end{array}$ & $\begin{array}{l}-0.036^{*} \\
(0.019)\end{array}$ & $\begin{array}{l}-0.012^{*} \\
(0.007)\end{array}$ \\
\hline 3 years after increase & $\begin{array}{l}0.049^{* *} \\
(0.021)\end{array}$ & $\begin{array}{l}-0.047^{* *} \\
(0.022)\end{array}$ & $\begin{array}{l}-0.028 \\
(0.023)\end{array}$ & $\begin{array}{l}-0.052^{*} \\
(0.029)\end{array}$ & $\begin{array}{l}-0.010 \\
(0.008)\end{array}$ \\
\hline 4 years after increase & $\begin{array}{l}0.054^{* * *} \\
(0.019)\end{array}$ & $\begin{array}{l}-0.051^{* * *} \\
(0.018)\end{array}$ & $\begin{array}{l}-0.026 \\
(0.022)\end{array}$ & $\begin{array}{l}-0.042 \\
(0.046)\end{array}$ & $\begin{array}{l}0.001 \\
(0.006)\end{array}$ \\
\hline Mean values & 0.329 & 0.657 & 0.521 & 0.355 & 0.0246 \\
\hline Observations & 4,147 & 4,147 & 4,147 & 4,147 & 4,147 \\
\hline$R^{2}$ & 0.758 & 0.749 & 0.815 & 0.621 & 0.785 \\
\hline
\end{tabular}

Note: Specifications include municipal and year fixed effects

Note: ${ }^{*} p<0.05 ;{ }^{* *} p<0.01 ;{ }^{* * *} p<0.001$ 
Acknowledgements We thank the editor Shuaizhang Feng and two anonymous reviewers for helpful comments and suggestions. We also thank our collegues at Kela and Åbo Akademi University, participants at the 30th EALE Conference in Lyon 2018, participants at the Nordic ESPANet conference in Helsinki 2019, and in particular Petri Böckerman, Ann-Zofie Duvander, Anita Haataja, Signe Jauhiainen, Aleksi Karhula, Anneli Miettinen, Miia Saarikallio-Torp, and Marcus Tamm for valuable comments to previous versions of the paper.

Funding Open access funding provided by Abo Akademi University (ABO).

Open Access This article is licensed under a Creative Commons Attribution 4.0 International License, which permits use, sharing, adaptation, distribution and reproduction in any medium or format, as long as you give appropriate credit to the original author(s) and the source, provide a link to the Creative Commons licence, and indicate if changes were made. The images or other third party material in this article are included in the article's Creative Commons licence, unless indicated otherwise in a credit line to the material. If material is not included in the article's Creative Commons licence and your intended use is not permitted by statutory regulation or exceeds the permitted use, you will need to obtain permission directly from the copyright holder. To view a copy of this licence, visit http://creativecommons.org/licenses/by/4.0/.

\section{Declarations}

Conflict of interest The authors declare no competing interests.

\section{References}

Aalto AM (2018) Incentives and inequalities in family and working life. Ph.d. thesis, Uppsala University, Uppsala, Economic Studies 176

Abadie A, Athey S, Imbens G, Wooldridge J (2017) When should you adjust standard errors for clustering? ArXiv e-prints, http://adsabs.harvard.edu/abs/2017arXiv171002926A

Allison PD (2009) Fixed effects regression models. no. 160 in Quantitative applications in the social sciences. SAGE Publications Inc., Thousand Oaks

Apps P, Rees R (2004) Fertility, taxation and family policy. Scand J Econ 106(4):745-763

Becker GS (1991) A treatise on the family revised and enlarged edn. Harvard University Press, Cambridge Massachusetts

Berg V, Rotkirch A (2014) Faster transition to the second child in late 20th century Finland: a study of birth intervals. Finn Yearb Popul Res 49:73-86

Burgess S, Gregg P, Propper C, Washbrook E (2008) Maternity rights and mothers' return to work. Labour Econ 15(2):168-201

Cukrowska-Torzewska E, Matysiak A (2020) The motherhood wage penalty: a meta-analysis. Soc Sci Res 88-89:102416

Engster D, Stensöta HO (2011) Do family policy regimes matter for children's well-being? Social politics: international studies in gender. State Soc 18(1):82-124

Erlandsson A (2017) Child home care allowance and the transition to second- and third-order births in Finland. Popul Res Policy Rev 36(4):607-630

Fitzenberger B, Sommerfeld K, Steffes S (2013) Causal effects on employment after first birth—a dynamic treatment approach. Labour Econ 25:49-62

Gerster M, Lappegård T (2010) Mother's employment and fertility in Norway Discussion Papers 624. Statistics Norway, Oslo

Giuliani G, Duvander AZ (2017) Cash-for-care policy in Sweden: An appraisal of its consequences on female employment. Int J Soc Welf 26(1):49-62

Gutiérrez-Doménech M (2005) Employment after motherhood: a European comparison. Labour Econ 12(1):99-123 
Hegewisch A, Gornick JC (2011) The impact of work-family policies on women's employment: A review of research from OECD countries. Community, Work \& Family 14(2):119-138

Kangas O, Rostgaard T (2007) Preferences or institutions? Work-family life opportunities in seven European countries. J European Social Pol 17(3):240-256

Kela (2013) Statistical yearbook of the social insurance institution 2012. Official statistics of Finland, Kela, Helsinki

Kela (2016) Statistical yearbook of the social insurance institution 2015. Official statistics of Finland, Kela, Helsinki

Kornstad T, Thoresen TO (2007) A discrete choice model for labor supply and childcare. J Popul Econ 20(4):781-803

Kosonen T (2014) To work or not to work? The effect of childcare subsidies on the labour supply of parents. BE J Econ Anal Pol 14(3):817-848

Kosonen T, Huttunen K (2018) Kotihoidon tuen vaikutus lapsiin. Tutkimuksia 115, Palkansaajien tutkimuslaitos, Helsinki

Kuhlenkasper T, Kauermann G (2010) Duration of maternity leave in Germany: a case study of nonparametric hazard models and penalized splines. Labour Econ 17(3):466-473

Lahtinen J, Selkee J (2016) Varhaiskasvatuskyselyraportti II: hallinto, kuntalisät, palveluseteli. Tech rep., Kuntaliitto, Helsinki

Lammi-Taskula J (2004) Äidit työmarkkinoilla - kahden kerroksen väkeä? Yhteiskuntapolitiikka 69(2):202-206

Leibowitz A, Klerman JA, Waite LJ (1992) Employment of new mothers and child care choice: Differences by children's age. J Human Res 27(1):112-133

Matysiak A, Vignoli D (2008) Fertility and women's employment: A meta-analysis. European Journal of Population / Revue europé,enne de Démographie 24(4):363-384

Miettunen L (2008) Lasten kotihoidon tuen kuntalisät osana suomalaista päivähoitojärjestelmää. Sosiaalija terveysturvan tutkimuksia 101, Kela, Helsinki

Mincer J, Polachek S (1974) Family investments in human capital: Earnings of women. J Polit Econ 82(2, Part 2):S76-S108

Naz G (2004) The impact of cash-benefit reform on parents' labour force participation. J Popul Econ 17(2):369-383

OECD (2018) Is the last mile the longest? Economic gains from gender equality in nordic countries. OECD Pubishing, Paris

Olivetti C, Petrongolo B (2017) The economic consequences of family policies: Lessons from a century of legislation in high-income countries. J Econ Perspect 31(1):205-230

Peutere L, Haataja A, Vahteran J, Kivimäki M, Pentti J, Virtanen P (2014) Heikentääkö kotihodon tuen kuntalisä äitien kinnittymistä työelämään? Yhteiskuntapolitiikka 79(3):291-305

Pronzato CD (2009) Return to work after childbirth: Does parental leave matter in Europe? Rev Econ Househ 7(4):341-360

Rønsen M, Sundström M (2002) Family policy and after-birth employment among new mothers-a comparison of Finland, Norway and Sweden. Eur J Popul 18(2):121-152

Räsänen T, Österbacka E, Valaste M, Haataja A (2019) Lastenhoidon tukien vaikutus äitien osallistumiseen työmarkkinoille Sosiaali- ja terveysturvan raportteja 14, Kela, Helsinki

Salin M, Hakovirta M, Ylikännö M (2016) Suhtautuminen ansaitsija-hoivaajamalleihin kuudessa Euroopan maassa. In: Haataja A, Airio I, Saarikallio-Torp M, Valaste M (eds) Laulu 573566 perheestä. Lapsiperheet ja perhepolitiikka 2000-luvulla, Kela, Helsinki, Teemakirja 15, pp 200-225

Salmi M, Närvi J (2017) Perhevapaat, talouskriisi ja sukupuolten tasa-arvo Raportti 4, Terveyden ja hyvinvoinnin laitos, Helsinki

Schøne P (2004) Labour supply effects of a cash-for-care subsidy. J Popul Econ 17(4):703-727

Säkkinen S, Kuoppala T (2018) Varhaiskasvatus 2017 tilastoraportti 32, Terveyden ja hyvinvoinnin laitos, Helsinki

Statistics Finland (2017) Statistical yearbook of Finland 2017. Official statistics of Finland 117, Statistics Finland, Helsinki

Takala P (2000) Lastenhoito ja sen julkinen tuki. Stakes, Kansaneläkelaitos, Helsinki

Ulker A, Guven C (2011) Determinants of maternity leave duration in Australia: Evidence from the HILDA survey. Econ Rec 87(278):399-413

Viitanen TK (2011) Child care voucher and labour market behaviour: experimental evidence from Finland. Appl Econ 43(23):3203-3212 
Ylikännö M, Hakovirta M, Salin M (2016) Miten perhevapaat tulisi jakaa äidin ja isän kesken? Asenteet Suomessa ja muualla Euroopassa. In: Haataja A, Airio I, Saarikallio-Torp M, Valaste M (eds) Laulu 573566 perheestä. Lapsiperheet ja perhepolitiikka 2000-luvulla, Kela, Helsinki, Teemakirja 15, pp 226-249

Publisher's note Springer Nature remains neutral with regard to jurisdictional claims in published maps and institutional affiliations. 